\title{
Comparative Analysis of Twelve Dothideomycete Plant Pathogens
}

\author{
Robin Ohm ${ }^{1}$, Andrea Aerts ${ }^{1}$, Asaf Salamov ${ }^{1}$, Steven Goodwinr ${ }^{2}$ and Igor Grigoriev ${ }^{1}$ \\ ${ }^{1}$ DOE Joint Genome Institute and ${ }^{2}$ USDA ARS Purdue University Campus \\ ${ }^{1}$ To whom correspondence may be addressed. E-mail: raohm@lbl.gov.
}

March 14, 2011

\section{ACKNOWLEDGMENTS:}

The work conducted by the U.S. Department of Energy Joint Genome Institute is supported by the Office of Science of the U.S. Department of Energy under Contract No. DE-AC0205CH11231. Additionally, we wish to thank and acknowledge the following for their efforts: Rosie Bradshaw, Lynda Ciuffetti, Richard Hamelin, Barbara Howlett, Gert Kema, Christopher Lawrence, Richard Oliver, Joey Spatafora \& Gillian Turgeon.

\section{DISCLAIMER:}

This document was prepared as an account of work sponsored by the United States Government. While this document is believed to contain correct information, neither the United States Government nor any agency thereof, nor The Regents of the University of California, nor any of their employees, makes any warranty, express or implied, or assumes any legal responsibility for the accuracy, completeness, or usefulness of any information, apparatus, product, or process disclosed, or represents that its use would not infringe privately owned rights. Reference herein to any specific commercial product, process, or service by its trade name, trademark, manufacturer, or otherwise, does not necessarily constitute or imply its endorsement, recommendation, or favoring by the United States Government or any agency thereof, or The Regents of the University of California. The views and opinions of authors expressed herein do not necessarily state or reflect those of the United States Government or any agency thereof or The Regents of the University of California. 
